\title{
International Aid Community, its Presence in the Post-conflict Reconstruction and Impact on Urban Legacy - Case Study of Prishtina
}

\author{
Arta Basha-Jakupi \\ University of Prishtina, Faculty of Civil Engineering and Architecture, Kosovo \\ e-mail: arta.jakupi@uni-pr.edu
}

\section{Violeta Nushi}

University of Prishtina, Faculty of Civil Engineering and Architecture, Kosovo e-mail: violeta.nushi@uni-pr.edu (corresponding author)

\begin{abstract}
A multifaceted process of reconstruction during the post-conflict time has an impact on all vital segments of life in the conflict-affected countries. For that reason, different approaches, efficient coordination and clearly defined and shared common goals are required. Aid programs are not the same everywhere and they greatly differ in priority levels, state of emergency and importance. Thus there are programs whose success is, unfortunately, closely related to the violation or neglect of existing standards which seem to become less important. The international aid intervention, be it in Kosovo or any other post-conflict country, is carried out according to the post-conflict reconstruction framework, with differences regarding the nature of conflict and the local context. In the case of Prishtina, as this study reveals, the issues involving the international community stay and accommodation in the city have not been adequately addressed. The community, which consists of both human and physical component, large in number and size, inevitably has a noticeable impact on the urban layout. The study uses grounded theory in the mixed methods inquiry and places the effects of the international community presence into a wider reconstruction process framework. It examines the initial claim that the post-conflict urban development is affected by the international community presence and that a proactive and multi-disciplinary approach to the reconstruction process should be adopted in order to rebuild complex socioeconomic and spatial systems in a more holistic and systemic way. ${ }^{1}$
\end{abstract}

Key words: urban planning, architecture, international community, offices, accommodation, post-conflict reconstruction, Prishtina.

$\mathbf{1}$ This study is a derivative of Arta Basha - Jakupi's doctoral research done at the Bauhaus University Weimar \& Germany, Institute for European Urban Studies, under the mentorship of Max Welch Guerra, PhD, financed by Madeleine Albright scholarship and the University of Prishtina scholarship. The survey was carried out in Kosovo, September to November 2011, by the author herself. The final version of the article was done in collaboration with Violeta Nushi as co-author, thus adding a valuable scientific component to the paper. 


\section{Introduction}

Academic and professional perspectives on the post-conflict development cover different aspects of international organizations and their intervention: how and when they deliver aid, their programs, cooperation and communication among various organizations, donors, partners, projects and many more activities that are supposed to help rebuild the state.

Recovery requires speed and accountability as well as their mutual balance. The priority of the international community is to design and implement the right instruments when helping the population in need to rebuild their lives and hopes. Intervention planning shows that every institution or organization has a specific aim and a precise program how to help the country. The ongoing debate on the international organizations (IO) performance is in search of extracting as much as possible from their presence in post-crisis countries. There has been a lot of investigation on the IO activities, on their coordination and how they should fit into local settings.

In one segment of this research it is suggested that international organizations do not deliver help only through their mandate and projects; their physical establishments can also enhance the ultimate goal of sustainability. The issue has not been treated seriously enough by the professionals or academics whilst it has caused concern on the local scene. The concentration of the IO offices and rented apartments in neighbourhoods not designed for hosting such kind of activities has changed the look, the value and the spirit of the place. While meeting the IO requirements and making them high rent lease holders, the inhabitants have built/rebuilt/changed/ their own districts or moved out of them.

This study aims at finding out what impact the international organizations have had on the city, aside from their programs and mandates. The survey examines the general attitude of the local population toward the changes that have occurred in their city due to the presence of the international organizations and the future development after their departure.

\section{Post-conflict Reconstruction}

After a conflict, peace is not easily restored. Poverty, ethnic, political or religious opposition, non-existent governments, a large number of arms - these are some of the essential problems (Read, 2008) which, if not addressed, can draw a country back into conflict and cause the snowball effect in the whole region.

In the contemporary world, a violent conflict is not only of local interest. It concerns the safety and welfare of the rest of the world. Indeed, the number of developing countries that have been a scene of civil conflict is such that the post-conflict development has become the norm rather than the exception (Gerd and Verkoren, 2005). Therefore, the post-war reconstruction, according to Sultan Barakat, has to address the following issues: 
1. give support to the affected communities in organizing their activities and regaining control over their environment

2. recognize the causes and the perception of the conflict and talk about them

3. establish a common vision among the stakeholders and be locally rooted (Sul$\tan , 2005: 11)$.

In many aspects of the post-conflict development, reconstruction has become physical, political and economic construction (Harrison, 1990). Reconstruction issues differ across regions and cultures, there is no "one size fits all" that can support and maintain peace. Conflict-affected societies share common concerns that peace processes and the IO involvement try to handle (Anderlini and El-Bushra, 2007). This is a study of urban/city development because the biggest concentration of international organizations is likely to be in urban centers, where changes happen on a much more extensive scale.

"No. Cities are not built by architects or urban planners... Cities are built by investors; by politicians; by lawyers and by technicians; last but not least, cities are built by the people, by the rich and the poor, by the educated and the illiterate, by the long established urban families and rural immigrants; and in the case of the postconflict city, by refugees and IDPs coming from all kinds of backgrounds and experiences." (Schacher, 2004)

The capital city of Kosovo, Prishtina, is the administrative, educational, political and cultural center of Kosovo and the most populous municipality. A huge influx of people from other parts of Kosovo to Prishtina after the 1999 conflict put tremendous pressure on the existing infrastructure in the municipality, from accommodation to public services and roads. It was a temporary home to a big number of international organizations on their mission to reconstruct the country. The reconstruction of the City of Prishtina just after the conflict was euphoric, the whole population acting as if it were in a state of emergency, with no time to plan. Emergency did not have the same meaning for all involved in the post-war rebuilding. The rush of the ones who were really needy caused the others in more secure positions to rush as well. It was a very convenient time to realize one's own plans and act in the name of emergency. The lack of any legislative framework enabled different actors to plan or rather not plan their actions. Actors identified as urban developers in the post-conflict city were planning institutions, residents, international organizations. They were directly or indirectly shaping the city in the post-conflict period, they were active and causing changes. These three sets of actors did not always work in harmony and their different impacts on the city need to be analysed along with their importance for the overall urban development of the city.

\subsection{Planning Institutions}

Some of the most serious threats to the city life are problems of fast urbanization, expansion of city boundaries, illegal construction, bad construction practices, overloaded infrastructure, outdated urban plans, weak institutional capacity, unemployment, social differentiation, environmental challenges. The strategies developed for 
post-conflict urban settings need to address these matters and adjust them to each unique urban context (UN-HABITAT, 2004).

Countries emerging out of conflict rarely have legitimate governments nor accord on how to form them; even when there is a government and most citizens recognize it, it is the war and the chaotic situation in its aftermath that disable the government from delivering adequate services (CSIS and AUSA, 2003). In the post-conflict Prishtina there were no state regulations and its development was directed by economic factors and private investors. The lack of proper legislation enabled individual construction of houses with no official permission for any kind of construction, which resulted in vast overbuilt areas of the city (Vockler, 2008:39). At first, the trend of illegal buildings was not prohibited by the authorities, the explanation being that it was part of the reconstruction process (Vockler, 2008:47). Sometimes, the municipality provided and approved construction permits called "urban consent"; although it did not legally recognize the status of property, the municipality still had some degree of control over informal or illegal building (Garstka, 2010). As Gartska notes, it was the best possible attempt by a weak and stressed out municipality to implement urban planning while it was experiencing widespread construction, rebuilding and in return migration during the post- conflict era. The response to urban chaos was the "Urban Strategic Plan 2020" (Figure 1) created by the city administration of Prishtina in 2004. It was made within the period of four months lacking the basic data (the number of residents, migration flows in and out the city) necessary for the real planning to start. It provoked a lot of reactions. According to the nongovernment organization ESI (European Stability Initiative), the loudest opponent of the plan, it was the lack of realism, focus and law enforcement that classified the plan as a failure (ESI, 2006).

Figure 1.

Prishtina Strategic Development Plan 2004
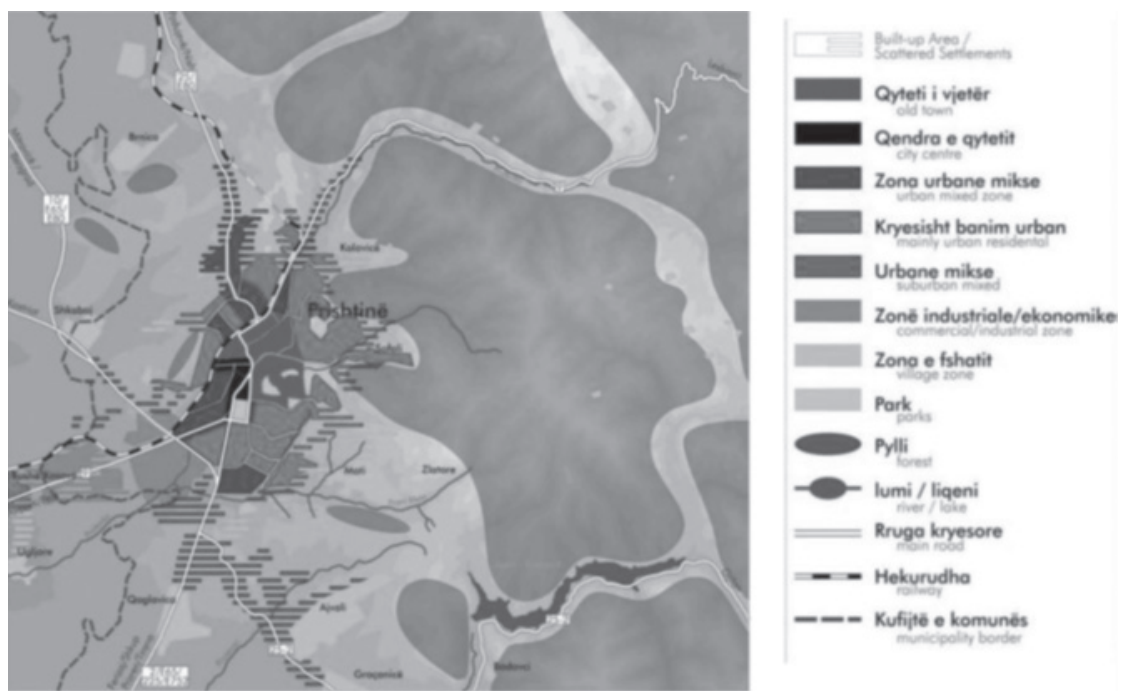

Source: The Department of Urban Planning and Construction, Prishtina (2004) 


\subsection{Residents}

Rural areas have suffered the biggest war damage. The unemployment rate has risen in rural areas due to the non-functional economic system, lack of raw materials and loss of the market. Poverty among the agro-rural population is high, and about 40 percent of the rural population is unemployed. Most of the labor force is unskilled or semi-skilled, and the lack of job opportunities is putting a strain on social cohesion and encouraging out-migration (as well as emigration) (World Bank, 2016). According to the UNFPA (United Nations Population Fund) migration study of the seven cities in Kosovo, the largest migration is to the capital city of Prishtina.

The city has gone through several restructuring phases affected by different cultural and political changes, the final result being the loss of urban culture and architectural spirit of the city. The post-conflict period is characterized by uncontrolled urban development (stimulated by private initiatives for business and residential construction) and suffocation of public space. Illegal building has degraded the urban structure and caused unplanned growth of the City of Prishtina. The city and its outskirts have become densely populated, with no adequate communal infrastructure and barriers which do not allow for further structured growth of the city.

The city becomes a testing ground by cultivating new urban/architectural forms. "In that period individual initiatives replaced the city's primary systems in domains like trade, housing production and even public services. This fast and dynamic process created hybrid systems - in which self-organized 'solutions' played a major role" (Djokic and Kucina et al, 2003). Most buildings test the limits by going beyond the acceptable, where the desire for profit pays no attention to state regulations and fears no penalties.

\subsection{International Organizations}

International organizations, an important contributor to the international ecosystem, play a vital role in the coordination of many economic, social, political, military and cultural issues. The Western Balkans countries have been a beneficiary of big foreign assistance through international organizations, humanitarian and bilateral agencies, intended for the post-conflict reconstruction (VIIES, 2006). International aid efforts comprise a wide range of activities consisting of humanitarian assistance, return of refugees and IDPs, reconstruction of the infrastructure systems, establishment of democracy and the rule of law, institutional and capacity building, social cohesion and development, economic regeneration, creation of the market economy, poverty alleviation and many others.

According to USAID N.G.O. Sustainability Index for 2006 "the number of NGOs registered in Kosovo remains at approximately 3,800. But only 150 are well-established and active". Immediately after the conflict approximately 300 international aid agencies were registered as active in Kosovo. The lack of employment forced young Kosovars to move from villages to towns and from towns to the capital as the only city with a growing tertiary economy, owing to (temporary) international presence (D'hondt, 2007). But gradually and systematically, the international community start- 
ed phasing down by going to other conflict zones or simply because there was no more work for them in Kosovo. The presence of the international community was short and in some cases what they left behind was short-lasting. In others, however, the traces are still visible after their departure. Their temporary overcrowding has left behind permanently abandoned space, tailored specifically to fit the IO needs and unsuitable for other purposes. Some of the former international community neighbourhoods are not centrally located and therefore not attractive to new potential renters. Nor do they have any special advantages or use for other functions. Huge, abandoned buildings and oversized houses in residential areas is something the international community will be remembered for. They affected the city not only by their projects, but also by their presence. Being in the city and exercising their daily activities, they brought along the new spirit and culture. All this cannot be neglected as it played a very important role in the urban development of the city as well as in the overall reconstruction process. The impact of the international community, however, did not have a label on it. The major changes happened indirectly through different means and actors. The executor was the local factor while the internationals were acting as a driving force. The changes were mainly generated by private interests which did not correspond to the overall public interest.

International organizations consist of international employees and local beneficiaries (biotic factors) who function together with all non-living physical (non-biotic) factors in their environment. Looking at the big picture of the post-conflict reconstruction, it can be seen that each small component can contribute to better assistance efforts. So the diversity of issues, their interconnectedness, the dynamics and complexity of change need to be taken into account. It is crucial to look for patterns and relationships between various issues in the post-conflict environment (Hasic, 2004:2).

\section{Methodology of Inquiry}

The rationale behind the use of grounded theory as a strategy of the mixed methods inquiry lies in the fact that there is no consistent theory for the study of the postconflict reconstruction (Hasic, 2004:38). Therefore, conducting the research which attempts to create an interrelated theory can be useful in this matter. Starting from the quantitative data gathered from the experiences of a large number of participants, the study later undertakes a more in-depth investigation done in a qualitative manner. The qualitative strategy of the study seeks to get a deeper understanding of urban development, taking into account the post- conflict setting in all its complexity.

The survey collects the necessary information including all categories of population at a specific point in time. It is a snapshot of the current situation through the application of the cross-sectional survey. The impact of international community on urban development of Prishtina comprises the interrelation of two variables. The international community and the local citizens both need to be included in the sample frame and the general approach used in the sampling method is probability sampling. The obvious difference in size of both groups leads to the usage of cluster sampling. The first group consists of the international population who lives and works in Prishtina while the second group is the local population. The groups differ in number of members but need to be brought to the same level of examination. The focus of this study are the internationalized parts of the City of Prishtina, which 
automatically elevates the importance of the international group to the same level as the local population, far bigger in number. Seeing these two sets of population as equal is requested by the research problem of the study. Cluster sampling is regarded as a more realistic approach to surveys because it samples groups or clusters of elements rather than individual elements (Lee et al, 1989).

In the two-phase cluster sampling, a random sampling technique is applied to the elements from each of the selected clusters. The members inside the two identified groups are chosen by using a simple random sampling technique. Different areas of the city differently benefit from the international presence. To avoid the mistake of getting the same set of respondents, the samples are taken from different parts of the city of Prishtina; thus different sections of population have the same probability of inclusiveness. A numbered grid is put on the map and a random number table is then used to select which squares to sample in. Therefore the locations where the survey is conducted (Figure 2) are a systematic random sample of areas at evenly spaced intervals, every second square on the grid. This method leads us to select $\mathrm{n}$ units (from the overall size N) so that every one of the NCn possible samples has an equal chance of being chosen. Sample Size estimate was done according to the Australian National Statistical Service. Determining random sample size is based on

1. the specification of the number of people in the entire group; in Prishtina there are around 150,000 inhabitants aged $18-65$ which is the appropriate age for being able to do some critical thinking on the issue

2. the decision about the level of accuracy which is acceptable; in this case the 95\% confidence level was used and margin errors within $\pm 5 \%$

Figure 2.

Grid Map of Prishtina, indicating zones where the survey was conducted

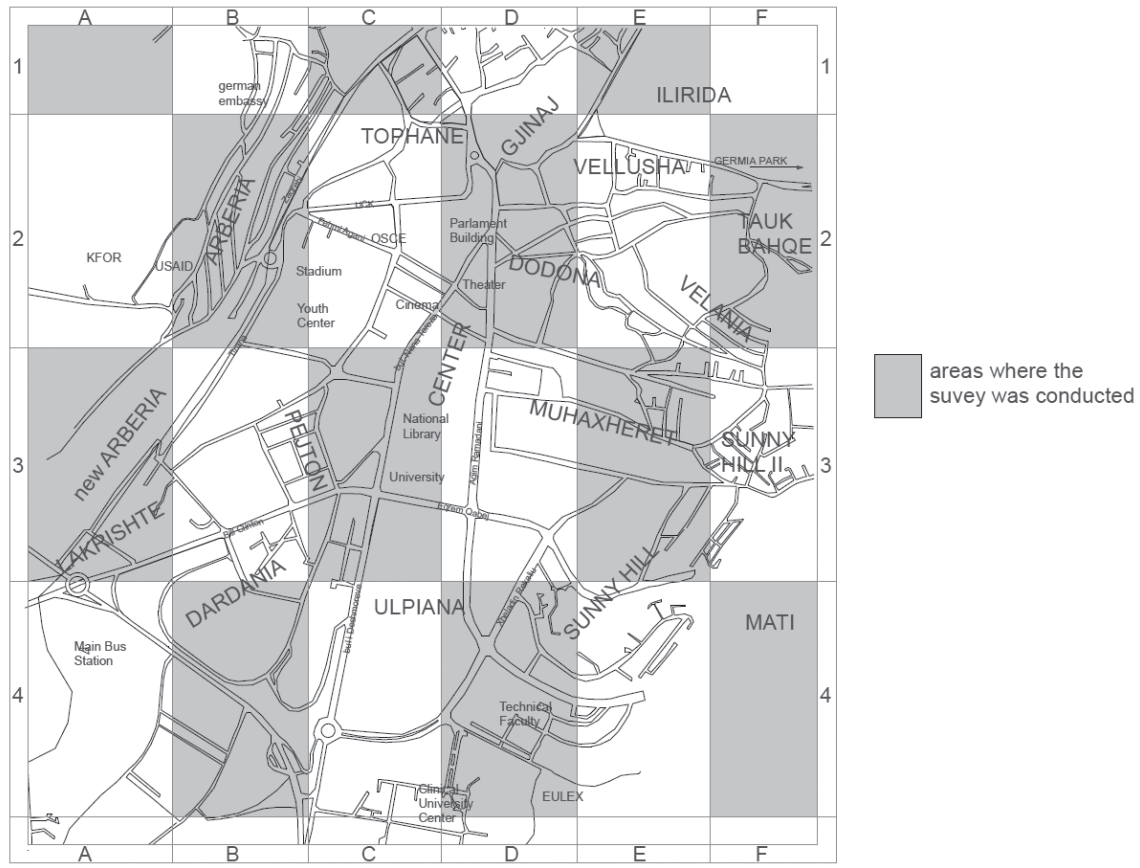


Taking into consideration the above given parameters, the sample size of this research study is 384 , which is within the requested number of respondents for a convincing research study.

The qualitative phase of the mixed inquiry plays the dominant role in this study. The quantitative method helps to identify the areas of concern by giving the big picture constructed by a large number of participants. The qualitative study involves the collection of multiple forms of data and a considerable amount of time spent on the site while attaining information. The instruments for data collection are observation, interview, textual documents and visual data.

The advantage of grounded theory is that it can be used to analyze any kind of data. So the purpose of using the mixed method inquiry is to get as feasible, valid and broad variety of data as possible in order to create a solid integrated theory of a wider reality.

\section{Discussion and Analysis}

As mentioned in the previous chapter, the methodology of inquiry consists of two phases, the quantitative phase followed by the qualitative one.

The intention of this two-phase, sequential mixed method study is to gain statistical, quantitative data from a sample and then follow up with a few examples to examine the results in in-depth qualitative research (Creswell, 2002). In the first phase, quantitative research questions address the impact of the international community presence on the post-conflict city, with the international community physical and social set up and the city urban development as variables, international population and local population as participants and the city of Prishtina as the research site. In the second phase, qualitative observations, visual data and official documents are used to explore urban changes caused by various aspects of the international community presence in some neighborhoods of Prishtina.

Research findings in Kosovo bring up some new issues which can only be analysed in an in-depth qualitative manner taking into account political, social, and cultural aspects of the country.

The main category emerging from the data is urban development, whereas sub codes identify various urban development aspects such as urban geography, built environment, urban economy, social infrastructure.

URBAN GEOGRAPHY Setting up offices and accommodation for the international community members was not foreseen in any of the formal plans. The policy of where and how they should be established was created in accordance with safety requirements, safety being the biggest concern at the beginning of the post-conflict reconstruction. With the passing of time, when safety was not an issue any longer, there were other factors which determined the establishment of an office or apartment from which to carry out daily activities. 
Urban geography deals with the growth and change of the city (Hutchison, 2010). The magnitude of growth and change in Prishtina has been large and degrading. This study reveals the main actors involved and the fact that they are all responsible for the extent of the damage done to the city. The survey shows that some of the local actions were prompted by the international community requests. 34\% of the respondents put the location as the most important factor when choosing accommodation beside comfort, security and price. Consequently, rents in attractive neighbourhoods were high and the locals willing to do anything to get money from the well off international community. Therefore it is not surprising that the most popular locations were most affected by changes either because the international tenants directly requested them or local landlords took the initiative themselves.

Arberia is a part of Prishtina which has hosted a big number of international organizations. Arberia used to be known as a residential area and was designed as such. Therefore, when it suddenly became a host to 46 organizations, change was to be expected, either in size or form. There were employees living/working there, beneficiaries who frequented them, not to mention all other services that accompanied the activities and functions of the international community. When the current situation is analysed, it appears that Arberia is still a "hot spot" for the international community set up (Figure 3), except that nowadays the majority of organizations belong to diplomatic missions and there is no particular grouping according to the country of origin as was the case back in the year 2000.

Figure 3.

Distribution of the International Offices in Arberia

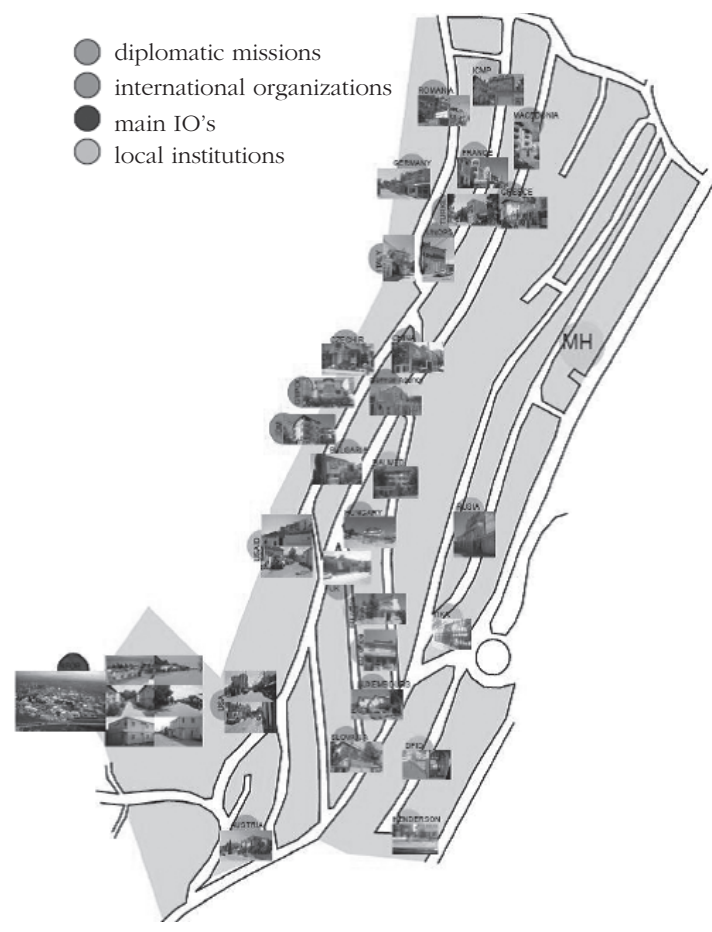


Figure 4.

Derivative from the International Community survey

\begin{tabular}{|l|c|c|}
\hline & $\begin{array}{c}\text { In which part of } \\
\text { Prishtina do you live? }\end{array}$ & $\begin{array}{c}\text { Which is the best residential } \\
\text { neighborhood in Prishtina? }\end{array}$ \\
\hline Arberia & $31 \%$ & $31 \%$ \\
\hline Sunny hill & $15 \%$ & $5 \%$ \\
\hline Peyton & $10 \%$ & $15 \%$ \\
\hline Dardania & $2 \%$ & $5 \%$ \\
\hline Center & $18 \%$ & $8 \%$ \\
\hline Velania & $3 \%$ & $5 \%$ \\
\hline Taslixhe & $13 \%$ & $13 \%$ \\
\hline Germia & $3 \%$ & $5 \%$ \\
\hline Lakrishte & $0 \%$ & $0 \%$ \\
\hline Ulpiana & $0 \%$ & $2 \%$ \\
\hline Dodona & $2 \%$ & $0 \%$ \\
\hline Veternik & $2 \%$ & $3 \%$ \\
\hline Don't Know & $0 \%$ & $10 \%$ \\
\hline No answer & $3 \%$ & $0 \%$ \\
\hline & $100 \%$ & $100 \%$ \\
\hline
\end{tabular}

Arberia continues to be the best neighbourhood for the international community (Figure 4), be it for safety reasons or because the place has already experienced the necessary changes following the international community requests. Another thing is that IOs tend to cluster in one neighborhood so they can benefit from each other, including their competitors. Such is the case with NGOs or other big government organizations which also get together so they can benefit from the knowledge spillover.

BUILT ENVIRONMENT refers to man-made surroundings that provide setting for people's everyday activities ranging from buildings, parks to entire neighbourhoods and the whole city. Built environment is the physical arrangement of the city which, together with other elements of development such as politics, economy etc., attempt to create conditions for normal urban life.

Reconstruction is usually the most immediate activity after the conflict. In reality, however, people most in need of a shelter are not the same people who do the rebuilding, have the money and power and use the opportunity to their advantage (Vockler, 2008:41). When dealing with the problem, it is important to understand various motives that drive them to act. The assumption is that certain local citizens' activities are indirectly prompted by the international community requests. The areas occupied by the international community have experienced the biggest changes in use, size and structure. Local people think that the most negative facet of the international community presence are overcrowded and occupied neighbourhoods (Figure 5), whereas 17\% of local residents find the change of use, from residential to offices, the most disturbing (Figure 6). 
Figure 5.

Derivative from the questionaries'

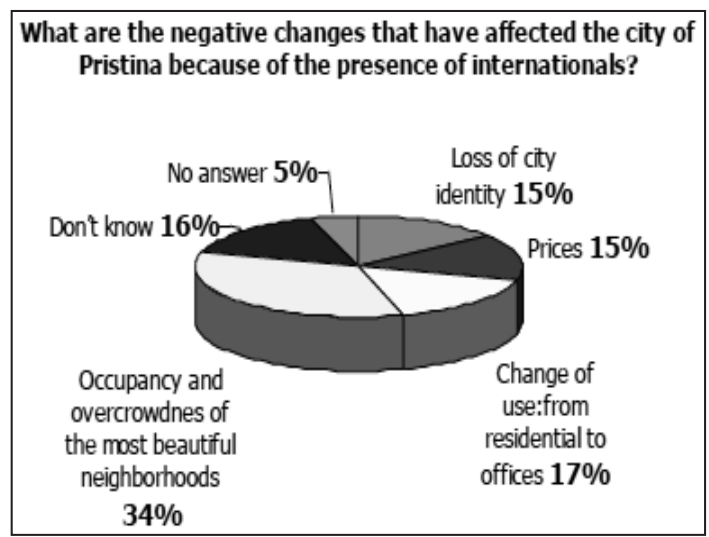

Figure 6.

Arberia residential neighborhood

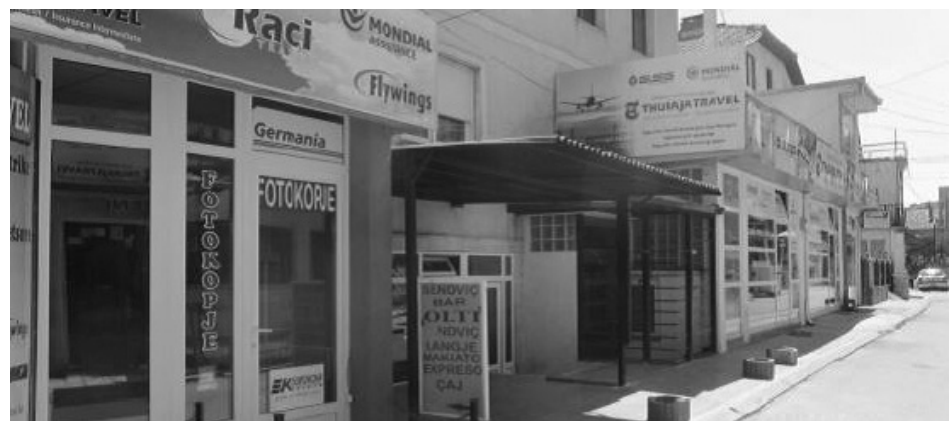

Source: author

Typical housing in Arberia used to be $\mathrm{P}+1+$ loft of a size shown in Figure 7 , in accordance with the Regulatory Plan indicating residential use. Nowadays, the neighbourhood looks different and caters for the international community needs (Figure 8).

Figure 7.

Typical housing in Arberia, $\mathrm{P}+1$
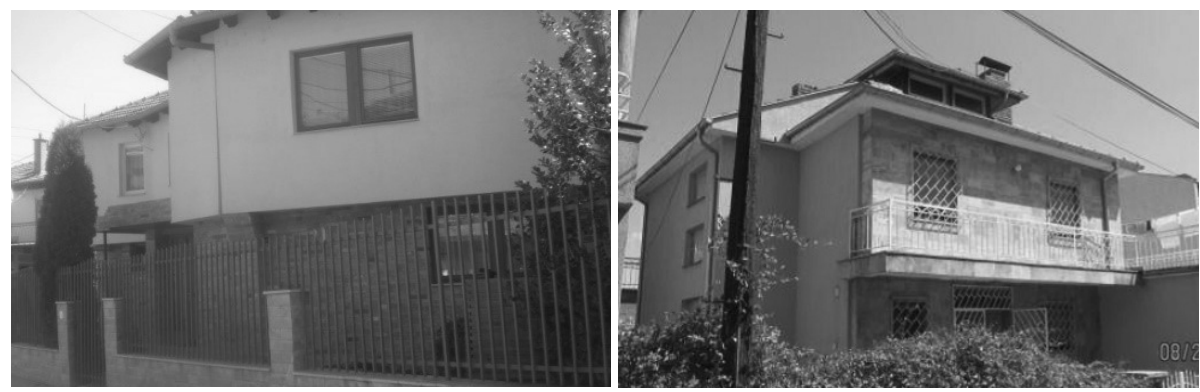
Figure 8 .

Arberia houses when rented to the International Organizations offices

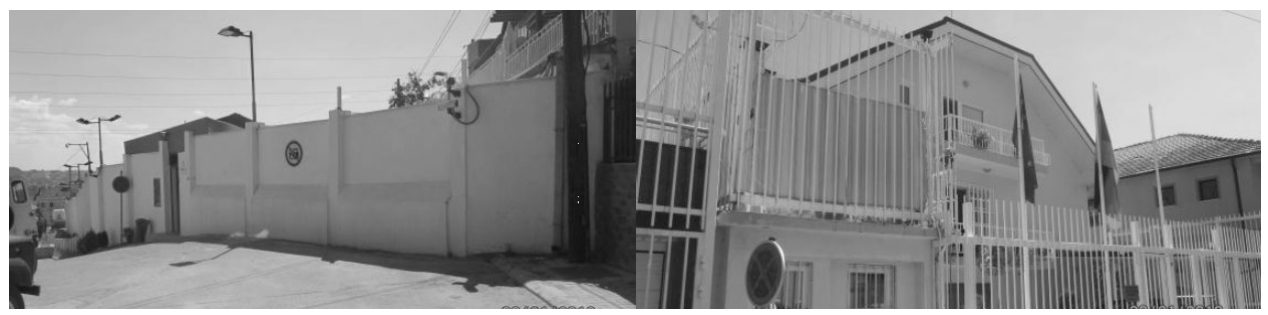

The presence of the IOs has changed the appearance and the identity of the city. Entire neighbourhoods have turned into international quarters and the posh part of the city has been invaded, its image changing from a quite place to a very crowded and noisy one. The spirit of the city has changed because of the new and different use of the place. Such urban "planning" was acceptable to those who profited from it while the excluded part of the society had to put up with the changes in their city. The result of these construction activities is questionable regarding the technical quality and safety standards. This is a problem because urban structure of the city center has to be fully functional in the decades to come. The most frequent safety issues are blocked emergency lanes, the removal of load-bearing walls on ground floors so as to create shop space, addition of extra floors on top of buildings executed without professional supervision (Vockler, 2008:41). One interesting point raised by Vockler is the identity and image of the city, influenced by the westerners and the newcomers. The desire to be part of urban international culture has resulted in pale copies of traditions and norms of the western architecture (Charlesworth, 2006) which neglect the local context and are tasteless examples of "turbo architecture" (Vockler, 2008:51).

URBAN ECONOMY promotes strategies and policies that enable cities to realize their full economic potential. However, intra-urban decisions made on behalf of the international community have brought about differences in the price of land, housing and commercial space which cause social segregation with respect to income (Hutchison, 2010).

Highly paid international staff willing to spend a considerable amount of money on their apartments or offices have raised the real estate prices as well as prices of other services. $15 \%$ of the local population object to these practices and see them as the downside of the international community presence. Only 13\% of international respondents take into consideration the price when choosing their apartments. High rents do not put a burden on their finances as only $8 \%$ of the respondents find their apartments overpriced.

Social and neighbourhood segregation can be easily noticed, especially in those parts of the city which are not in the center and have never fostered any other activities beside being residential areas. The living conditions there are better compared 
to the rest of the city and the housing has been upgraded due to financial means from before.

Setting up the international community offices and living quarters has affected the city development. Most IO members look for big, new houses and spend considerable amounts of money. Service industry arrives in areas around rented offices or apartments. Coffee bars, restaurants, DVD/CD stores, massage centers, brothels etc. flourish in no time (Vockler, 2008:39). As seen earlier in this research, there is a long chain of aid delivery through various mediators before the end beneficiary gets a reduced share of it. There are complaints about the long process of filtration of the assistance whereas, in the case of getting big money from high rents, the financial gain is quick and direct. It takes much more than money to set up a proper reconstruction foundation. In this case there is no political momentum and the implementation of financial programs and money injections seem excessively dominant (Hasic, 2004:25). As a consequence, the local population starts building, rebuilding and transforming their homes into big offices and fancy apartments in the hope of earning money from the rent.

SOCIAL INFRASTRUCTURE For 34\% of the local population, the occupancy and overcrowding of their most beautiful neighbourhoods are the downsides of the IO presence. The citizens feel that these parts of the city do not belong to them anymore since they are congested and do not allow people to live normal, everyday life. As a solution to the problem, $17 \%$ of the citizens would place the IOs in an area where they would have more free space. Another issue of concern is the belief that there is an international sub-city within the city of Prishtina. Its existence is proved by comparing the local citizens' mind map and the response of the international community. The local population was asked to mark the places known as international (Figure 9) due to a big concentration of offices, apartments, restaurants, coffee bars etc. where the international community members live, work and spend leisure time. By creating this sub-city, they shut themselves off from urban realities and live their shell-like existence. "Though living in the same country, the two bureaucracies-one international and well-funded from abroad, one national and almost always starved for funds-are conceptually (and in terms of available resources) miles apart and therefore rarely interact meaningfully. Foreign officials gravitate toward each other socially as well, through their clubs and other groups, thus creating segregated spaces of interaction" (Ghani and Lockhart, 2008:19).

"The offices of international organizations and NGOs are networked by means of new concrete buildings, with security guards and strict rules of access, all signs that mark them as places of privilege" (Ghani and Lockhart, 2008:19). The message these buildings and settings send to the citizens is not compatible with what the IOs claim: transparency, trust, cooperation etc. 
Figure 9.

Distribution of the International Community Residence; Offices; Restaurants according to the Local Community Mental Map

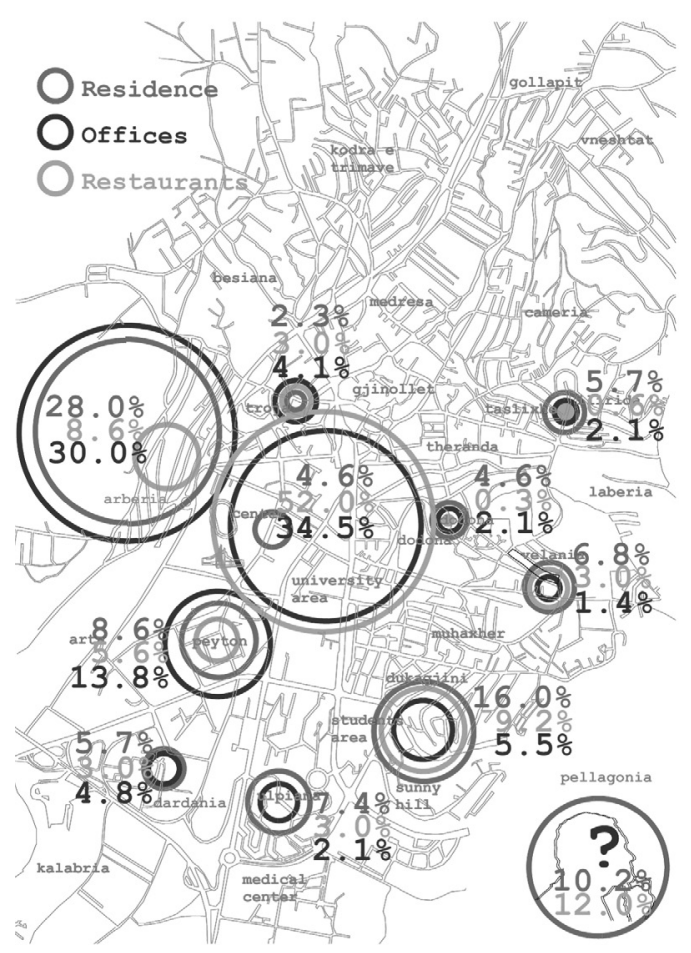

The non-profit organization Collaborative Learning Projects (CDA), in the Listen Project, reveals that the local people want the staff of aid organizations to be present and interact with them, so they can better understand their needs, respect their ideas and value their opinions, share and learn from each other (CDA, 2010). Not surprisingly, this request derives from the familiar reality in which the international community has a limited understanding of the people they serve, the dynamics of the national politics and economy, especially outside the capital city (Ghani and Lockhart, 2008:19).

\section{Conclusion}

As the analysis of the grounded data shows, the identified problems are caused by a common phenomenon. Generality among the substantial codes can be explained by the fact that they altogether form a network of relations which influence one another, under the main category of urban development of the post conflict city.

The grounded theory analysis of the quantitative and qualitative research findings points to the fact that the international community presence has brought great changes to the urban city life. The most noticeable change is uneven development of city neighbourhoods. In those parts of the city where there was a high concentra- 
tion of international organizations, a disproportionate amount of money was spent on the infrastructure repair to ensure a rapid delivery of services to the international community. Unfortunately, those were short-term solutions, with no plans for the future infrastructure maintenance. Furthermore, the study reveals social segregation, mostly visible between the local and the international community. Another form of social segregation exists among the local population: there are those who have profited from the international presence and those who have not benefited in any way and only experience the burden of the change brought about by the international community. In weak economies, a free market system fails to protect the most vulnerable groups of people before they have time to re-establish viable livelihoods; at the same time it increases the opportunities for the rich who have already benefited from the war (Sultan, 2005:250).

It would not be fair to say that the changes experienced by Prishtina citizens and caused by international organizations have been made with bad intentions. There is a category of people who have actually benefited from their presence. The problem is rather that it is not the right category. When and if accommodation facilities are properly governed, the complete urban layout can be rearranged and upgraded for the benefit of the whole community. The responsibility falls on government institutions because of their lack of involvement, planning and ad hoc solutions. The analysis shows that most problems are caused by the absence of relevant stakeholders' comprehensive/holistic approach to sustainable urban development.

Urban development of the city as the main category will be upgraded only when these issues are addressed and approached under one model with a set of concepts which provide understanding of these phenomena or form the basis for action with respect to them (Given, 2008). It often happens that, during the reconstruction process, international actors are closely linked to the ongoing program or project and everything else is of little importance to them. Everything is 'sacrificed' for the success of the project; it is rarely understood that an integrated and holistic approach is also possible which makes reconstruction efforts even more effective. The same is true for the physical and social establishment of the international community which could easily go hand in hand with the overall reconstruction effort.

\section{References}

1. Anderlini, S. N. and El-Bushra, J. (2007). Post Conflict Reconstruction in Inclusive Security, Sustainable Peace: A Toolkit for Advocacy and Action. Hunt Alternatives Fund Publications (HAF), 53-68.

2. Beck, U. (1992). Risk Society. Towards a New Modernity. London/Newbury Park/New Delhi: Sage Publications.

3. CDA Collaborative Learning Projects (2010). Initial Findings from the Listening project Report. Available at: www.cdainc.com/cdawww/pdf/other/ip 2page initial findings from the listening project 20100803_pdf.pdf. (Accessed 15 January 2017) 
4. Center for Strategic and International Studies (CSIS) and the Association of the US army (AUSA) (2003). Final Report of the bi-partisan commission on postConflict.

5. Charlesworth, E. (2006). Architects without frontiers: War, reconstruction and design responsibility. Elsevier Architectural Press.

6. Creswell, J. W. (2013). Research design: Qualitative, quantitative, and mixed methods approaches. Sage publications.

7. D' Hondt, F. (2007). Re-creating Kosova Cities. Available at: www.isocarp.net/ data/case studies/912.pdf. (Accessed 21 January 2017)

8. Djokic, A. and Kucina, I .et al. (2003). The Wild City. Available at: http://www. stealth.ultd.net/stealth/01 wildcity.html. (Accessed 18 November 2017)

9. European Stability Initiative (2006). Utopian Visions, governance failures in Kosova's capital. Discussion Paper. ESI.

10. Evans, G. and Newnham, J. (1998). The Penguin dictionary of international relations. London: Penguin Books, 235-236.

11. Garstka, G. J. (2010). Post-conflict urban planning: The regularization process of an informal neighborhood in Kosova/o. Habitat International, 34 (1): 86-95.

12. Junne, G. and Verkoren, W. (Eds.). (2005). Post conflict development: meeting new challenges. Lynne Rienner Publishers.

13. Ghani, A. and Lockhart, C. (2009). Fixing failed states: A framework for rebuilding a fractured world. Oxford University Press.

14. Given, L. M. (Ed.). (2008). The Sage encyclopedia of qualitative research methods. Sage Publications.

15. Harrison, S. S. (1990). After the Wars: Reconstruction in Afghanistan, Indochina, Central America, Southern Africa, and the Horn of Africa. Transaction Publishers.

16. Hasic, T. (2004). Reconstruction planning in post-conflict zones: Bosnia and Herzegovina and the international community (Doctoral dissertation, Infrastruktur).

17. Hondius, F. (1999). Recognition and protection of NGO-s in International Law. International Developments. The international.

18. Hutchison, R. (Ed.). (2009). Encyclopedia of urban studies (Vol. 1). Sage.

19. Lee, E. S.; Forthofer, R. N. and Lorimor, R. J. (1989). Analyzing Complex Survey Data (Sage University papers series. Quantitative applications in the social sciences; no. 07-071). Sage Publications.

20. Municipal Assembly Prishtina (2004). Prishtina Urban Development 2004-2020, Strategic Plan. The Department of Urban Planning and Construction.

21. Read, G. (2008). Architects without Frontiers: War, Reconstruction and Design Responsibility-Edited by Esther Charlesworth. Journal of Architectural Education, 61 (3): 65-66.

22. Schacher, T. (2004). Who builds a city? Development of Kabul Reconstruction and planning issues. In Architecture and behavior, Switzerland.

23. Sultan, B. (2005). After the Conflict: Reconstruction and Development in the Aftermath of War. London: IB Tauris.

24. The Vienna Institute for international Economic Studies/WIIW (2006). Western Balkans Economic Development since Thessaloniki 2003. 
25. UN-HABITAT, Commission on Sustainable Development (CSD 12) (2004). Sustainable Recovery in Post-Crisis Situations. Norwegian Ministry of the Environment.

26. USAID N.G.O. Sustainability Index for 2006. Available at: http://pdf.usaid.gov/ pdf docs/Pnadk556.pdf. (Accessed 25 November 2016)

27. Vockler, K. (2008). Prishtina is Everywhere. Turbo Urbanism, Architectura \& Natura.

28. Worldbank. (2016). Country Program Snapshot. Available at: http://pubdocs. worldbank.org/en/419461462386476530/World-Bank-Kosovo-Program-Snapshot-April-2016.pdf. (Accessed 11 November 2017) 


\section{Arta Basha-Jakupi}

Sveučilište u Prištini, Građevinski i arhitektonski fakultet, Kosovo

e-mail:arta.jakupi@uni-pr.edu

\section{Violeta Nushi}

Sveučilište u Prištini, Građevinski i arhitektonski fakultet, Kosovo

e-mail:violeta.nushi@uni-pr.edu

\section{Pomoć međunarodne zajednice u obnovi zemalja nakon sukoba i utjecaj njezina djelovanja na urbano nasljeđe - studija slučaja grada Prištine}

\section{Sažetak}

Višestruki proces rekonstrukcije u zemljama nakon sukoba dotiče vitalne aktivnosti života svake zemlje i zahtijeva različite pristupe, međusobnu usklađenost i stremljenje zajedničkom cilju. Programi pomoći nisu posvuda jednaki i razlikuju se po hitnosti djelovanja, pravu prvenstva i važnosti. Tako postoje programi pomoći zbog čijeg uspjeha dolazi do zanemarivanja nekih postojećih okolnosti ili grubog nasilja nad onim što se u tom trenutku smatra manje važnim. Djelovanje međunarodne zajednice na Kosovu ili u bilo kojoj drugoj zemlji u razdoblju nakon sukoba odvija se prema ranije utvrđenom programu rekonstrukcije, s manjim ili većim razlikama, ovisno o prirodi sukoba i lokalnom kontekstu. Ova studija otkriva da plan smještaja međunarodne zajednice nije cjelovito razrađen. Međunarodna je zajednica velik entitet koji se sastoji od ljudske/humane i fizičke komponente, te njezin utjecaj na izgled urbanog prostora u kojemu djeluje ne može proći nezamijećeno. Studija je bazirana na mješovitoj metodologiji istraživanja strategijom utemeljene teorije i analizirajući situaciju u Prištini postavlja učinke boravka internacionalne zajednice u širi okvir procesa rekonstrukcije. Istraživanje ispituje početnu postavku da prisustvo međunarodne zajednice u periodu nakon sukoba utječe na urbani razvoj. Procesu rekonstrukcije valja pristupiti proaktivno i multidisciplinarno u svrhu izgradnje cjelovitih i održivih socijalnih, ekonomskih i prostornih sustava.

Ključne riječi: urbano planiranje, arhitektura, međunarodna zajednica, smještaj osoblja, proces rekonstrukcije nakon sukoba, Priština. 